\title{
Sistem Informasi Geografis Pemetaan Daerah Aliran Sungai Berbasis Web
}

\author{
Sitta Rahayu ${ }^{\mathrm{a} 1}$, I Nyoman Piarsa $^{\mathrm{a} 2}$, Putu Wira Buana $^{\mathrm{a} 3}$ \\ aJurusan Teknologi Informasi, Fakultas Teknik, Universitas Udayana, Bali \\ Jalan Raya Kampus Unud, Bukit Jimbaran, Badung, Bali, Indonesia \\ 1'sitta_rahayu@yahoo.com \\ 2nyoman_piarsa@ftunud.ac.id \\ 3wbhuana@gmail.com
}

\begin{abstract}
Abstrak
Pengolahan Daerah Aliran Sungai sangat penting karena semakin terawatnya DAS akan semakin kecil pula resiko terjadinya bencana yang disebabkan oleh meluapnya air sungai. Perawatan DAS bisa dilakukan dengan baik jika informasi mengenai DAS tersebut lengkap, namun sampai saat ini informasi yang tersedia masih kurang. Hal ini disebabkan sulitnya untuk melakukan pengumpulan data DAS sehingga diperlukan sebuah sistem yang bisa digunakan untuk melakukan pengolahan data DAS. Sistem yang akan digunakan adalah Sistem Informasi Geografis Pemetaan Daerah Aliran Sungai Berbasis Web. Sistem ini merupakan sistem yang dapat dimanfaatkan untuk melakukan pendataan dan pemetaan DAS dengan menggunakan peta dari Google Maps. Fitur polyline yang dimiliki oleh Google Maps dapat digunakan untuk menggambarkan sebuah jaringan sungai dan panjang genangan banjir, library geometry digunakan untuk menghitung panjang polyline, fitur marker digunakan untuk menggambarkan lokasi bendungan dan titik rawan banjir dari sebuah sungai dan fitur polygon digunakan untuk menggambarkan batas DAS. Sistem ini melakukan pendataan DAS dengan dua cara, yaitu digitasi dan input koordinat yang dilakukan oleh admin. Hasil dari pendataan DAS dapat memberikan informasi bagi pengguna tentang lokasi bendungan beserta deskripsinya, jaringan sungai dalam DAS, titik rawan banjir, panjang genangan banjir dan batas dari DAS beserta deskripsinya.
\end{abstract}

Kata Kunci : DAS, Sistem Informasi Geografis, Google Maps, Web.

\begin{abstract}
Astract
Watershed management becomes very important because the more maintained its watershed, the risk for disasters caused by the overflowing river became smaller. Watershed management could be done if the information on that watershed could be complete, but untill this day, the available information was lacking. This condition caused the difficulty of data collected, so required a system that could be used to perform watershed data processing. A system that to be used is Geographic Information Systems Watershed Mapping. This system is a Web-based system that can be used for collected data and mapping the watershed using a map from Google Maps. Features polyline which was owned by Google Maps can be used to describe a network of rivers and long inundation, library geometry was used to calculate the length of polylines, feature marker was used to describe the location of the dam and the point was prone to flooding of a river and features a polygon used to describe the watershed. This system can collected data watershed in two ways, namely digitization and input the coordinates that can be done by the admin. Results from watershed data can provide information to the user about the location of the dam along with its description, the river network in the watershed, a point prone to flooding, inundation and limit the length of the watershed and its description.
\end{abstract}

Keywords : Watersheed, Geographic Information System, Google Maps, Web 


\section{Pendahuluan}

Perawatan tiap DAS dapat berbeda tergantung kondisi tiap DAS tersebut. DAS memiliki beberapa fungsi yang berbeda terkait elemen yang dimiliki oleh DAS tersebut seperti bendungan, jaringan aliran sungai, titik rawan banjir serta batas DASnya. perawatan DAS yang kurang maksimal dapat menyebabkan bencana banjir dan beberapa bencana lainnya. Perawatan DAS yang maksimal akan memberikan manfaat yang maksimal pula bagi kehidupan masyarakat seperti tetap stabilnya aliran sungai yang mengalir dengan adanya bendungan yang menjadi bangunan untuk menahan air yang berlebih ketika musim hujan tiba. Perawatan dan pemanfaatan DAS ini dapat dimaksimalkan apabila didukung dengan adanya pemetaan DAS yang baik sehingga memudahkan untuk perawatan dan pemanfaatannya.

Berbagai studi telah dilakukan mengenai DAS. Salah satunya adalah untuk mendukung analisis kondisi dan pemanfaatan sumber daya air berkaitan dengan pengolahan DAS yang dilakukan oleh Sifurridzal, Donny Harisuseno dan M. Basri mahasiswa Fakultas Teknik Jurusan Teknik Perairan Universitas Brawijaya, Malang. Ketiga mahasiwa tersebut melakukan penelitian untuk mengukur tingkat keberhasilan pengolahan DAS menggunakan data morfologi DAS dan morfometri DAS yang didapat dari hasil pemanfatan model ketinggian digital atau Digital Elevation Model (DEM) satelit pengindraan jarak jauh dalam analisis morfometri DAS dengan bantuan Sistem Informasi Geografis. Ketiga mahasiswa tersebut melakukan penelitian melalui pendekatan karakteristik parameter fisik DAS dengan menggunakan aplikasi Sistem Informasi Geografis[1].

Digital Elevation Model (DEM) satelit pengindraan jarak jauh yang digunakan untuk mendapatkan data spasial bukanlah hal yang buruk, karena dapat memudahkan pengembang untuk memetakan sebuah lokasi, tetapi tetap memiliki kekurangan. Pengumpulan data juga sebaiknya dilakukan secara manual yaitu melakukan pengumpulan data dari dinas terkait dan tidak hanya mengunakan Digital Elevation Model (DEM) satelit pengindraan jarak jauh, agar titik lokasi dan kondisi bahan penelitian bisa diketahui dengan akurat [1]. Berbeda dengan penelitian yang dilakukan oleh ketiga mahasiswa di atas, Sistem Informasi Georafis yang dikembangkan ini dibangun dengan menggunakan hardware, software komputer dan Google Maps API yang berfungsi untuk verifikasi data, kompilasi data, akusisi data, penyimpanan data, edit dan update data, perubahan data, pertukaran dan manajeman data, manipulasi data, pemanggilan dan presentasi data serta analisa data tanpa menggunakan DEM satelit pengindraan jarak jauh.

Sistem Informasi Geografis Pemetaan Daerah Aliran Sungai Berbasis Web ini diharapkan mampu membantu dalam perencanaan, pemanfaatan, pengendalian dan pengembangan sumber daya yang terdapat di DAS. Sistem ini dibangun dengan fitur untuk memetakan batas DAS, memetakan jaringan sungai induk dan sungai kecil, memetakan titik rawan banjir sepanjang aliran sungai, panjang genangan banjir dan lokasi bendungan yang terdapat di kabupaten sehingga memudahkan pemerintah dalam memantau dan melakukan pengambilan keputusan terkait pengolahan DAS di daerah terkait. Pemerintah juga dapat mengembangkan sumber daya yang terdapat di DAS daerah terkait berdasarkan kondisi georafis DAS tersebut.

\section{Metodologi Penelitian}

Penelitian ini menggunakan metode air terjun (waterfall). Metode waterfall terbagi dalam beberapa tahap meliputi : Analisis kebutuhan perangkat lunak (Requirements Definition), Desain sistem (System and Software Design), Implementasi dan Pengkodean (Implementation and Unit Testing), Integrasi dan Pengujian (Inegration and System Testing), Perawatan (Maintenance). Metode perancangan database dalam penelitian ini meliputi: perancangan basis data konseptual, logikal dan fisikal.

\subsection{Metode Perancangan Sistem}

Metode waterfall diawali dengan Requirements Definition kemudian proses desain sistem, dilanjutkan dengan pengkodean, kemudian implementasi dari hasil pengkodean dan integrasi dengan subsistem, jika pengkodean sistem telah berjalan sesuai dengan desain sistem dan bisnis proses maka dibuatkan dokumen atau laporan dan proses berhenti, jika hasil belum sesuai 
dengan desain sistem dan proses bisnis maka diulang pada tahap pengkodean. Tahap terakhir adalah perawatan atau maintenance.

Prinsip dasar dari metode waterfall jika diterapkan pada perancangan Sistem Informasi Geografis Pemetaan Daerah Aliran Sungai Berbasis Web ini dimulai dari tahapan pendefinisian kebutuhan informasi yang akan diberikan oleh Sistem Informasi dan software yang akan digunakan untuk membangun sistem informasi. Tahap kedua adalah tahap desain sistem informasi yang akan dibangun mulai dari tampilan untuk user interface sampai pada panel admin. Proses ketiga adalah proses pengkodean dan implementasi dari kode yang telah dibangun. Proses keempat adalah integrasi dengan subsistem yang terdapat dalam sistem. Proses kelima atau proses terakhir adalah proses perawatan atau maintenance sistem. Proses terakhir ini dapat dilakukan jika proses pengkodean dan integrasi dengan subsistem sudah berjalan sesuai dengan desain sistem dan bisnis proses.

\subsection{Gambaran Umum Sistem}

Salah satu perancangan sistem informasi ini berisi gambaran umum sistem dari sistem yang dikembangkan dan struktur database yang digunakan.

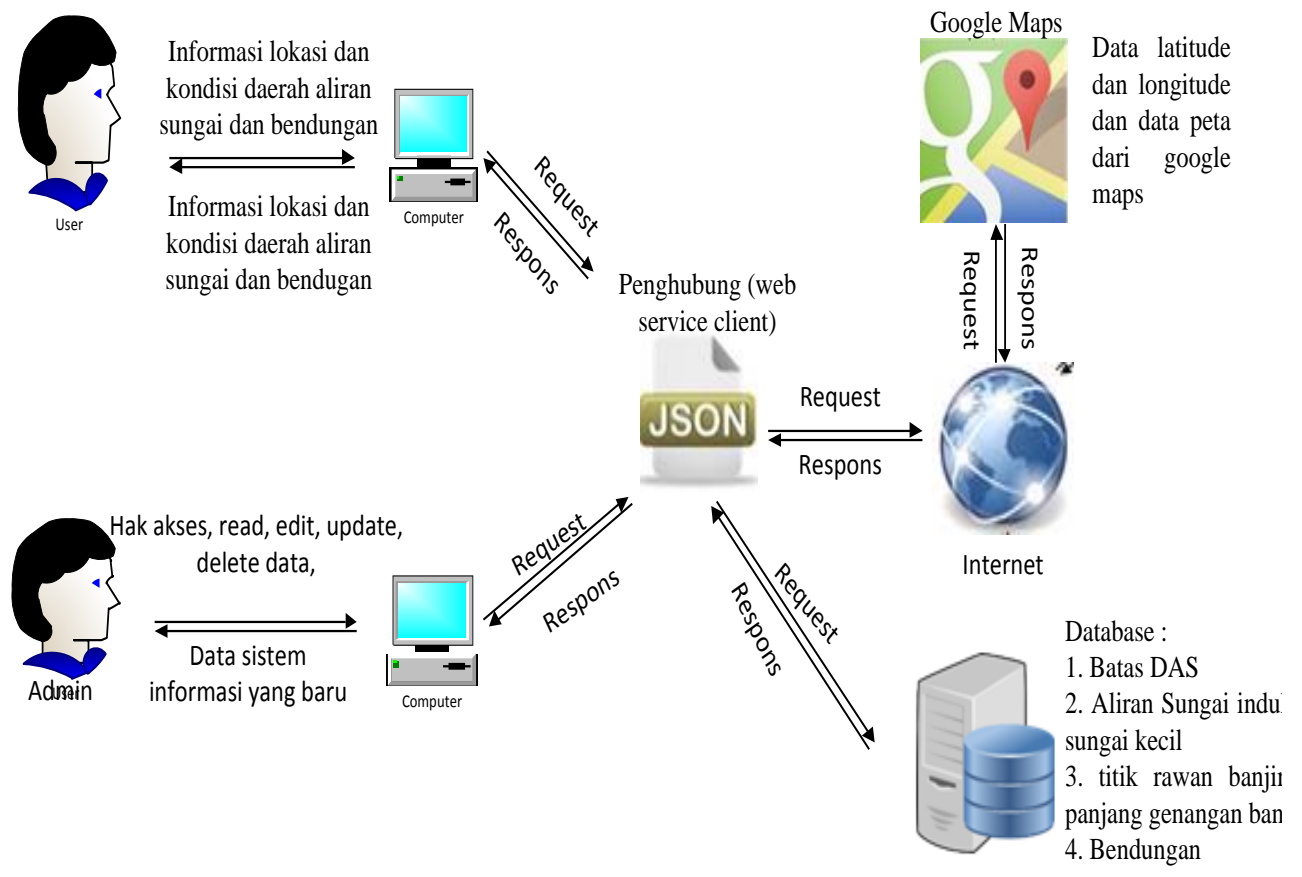

Gambar 1. Gambaran Umum Sistem

Gambar 1 merupakan gambaran umum sistem yang menjelaskan bagaimana Sistem Informasi Geografis ini dijalankan oleh user. Sistem Informasi Geografis ini memanfaatkan Google Maps untuk menampilkan peta dan menggunakan Google Maps API untuk mengelola peta tersebut. Database dari Sistem Informasi Geografis ini harus bersifat global, sehingga hal itu harus ditangani dengan memanfaatkan web server. Permintaan data dari database pada web tidak bisa dilakukan secara langsung, dikarenakan menggunakan bahasa pemrograman yang berbeda. Sistem Informasi Geografis ini memanfaatkan Json sebagai jembatan penghubung Sistem Informasi Geografis dengan web server tersebut, sehingga Sistem Informasi Geografis dapat mengakses database yang tersedia pada web server. Admin memiliki hak akses untuk memanipulasi data yang terdapat pada sistem informasi. 


\subsection{DFD Level 0 Sistem Informasi}

Perancangan Diagram Alir Data (DAD) atau dalam bahasa Inggris disebut Data Flow Diagram (DFD) adalah suatu diagram yang menggunakan notasi untuk menggambarkan alir dari data yang sangat membantu untuk memahami sistem secara logika, terstruktur dan jelas. DFD juga bisa dikatakan sebagai suatu model logika data atau proses yang dibuat untuk menggambarkan asal data dan tujuan data yang keluar dari sistem, tempat dimana data disimpan, proses apa yang menghasilkan data tersebut dan interaksi antara data yang tersimpan dan proses yang ditampilkan pada data tersebut. DFD ini merupakan alat perancangan sistem yang berorientasi pada alur data dengan konsep dekomposisi yang dapat digunakan untuk menggambarkan analisa maupun rancangan sistem yang mudah dikomunikasikan oleh profesional sistem kepada pemakai maupun pembuat program [2]. DFD Level 0 Sistem Informasi ini dapat dilihat pada Gambar 2.

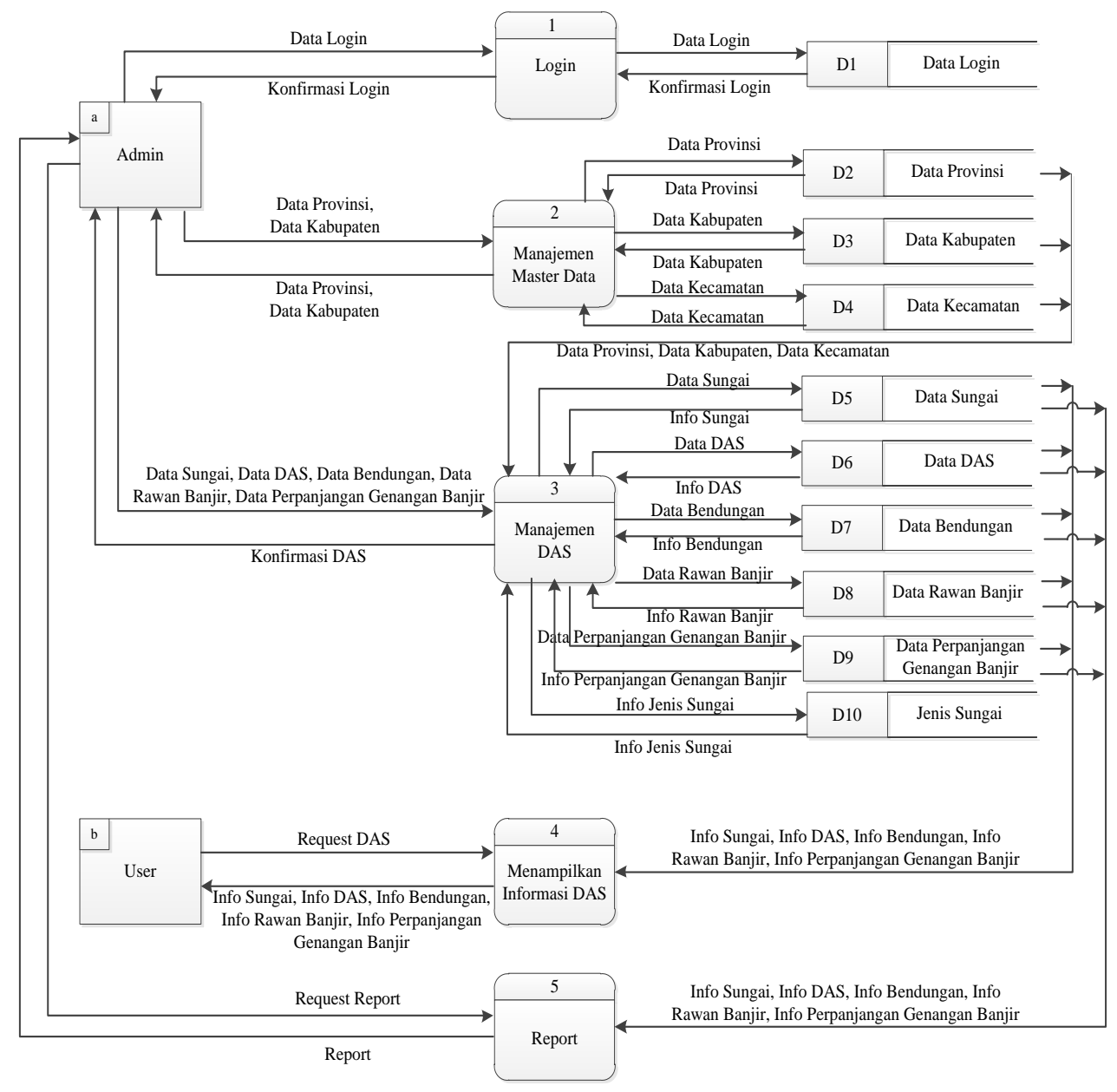

Gambar 2. DFD Level 0 SIG Pemetaan DAS

Gambar 2 menampilkan tentang proses yang terjadi pada sistem. Proses tersebut antara lain adalah proses Cek login, Manajemen Data Master, Manajemen DAS, Menampilkan Informasi DAS dan Report yang memiliki 10 data storage.

\subsection{Perancangan Database}

Sistem Informasi Geografis ini dirancang dengan menggunakan 10 tabel yang digunakan untuk menyimpan data. Struktur tabel yang digunakan pada database dalam Sistem Informasi Geografis Pemetaan Daerah Aliran Sungai Berbasis Web dapat dilihat pada Gambar 3.

Sepuluh tabel adalah tabel yang akan digunakan untuk menyimpan data DAS. Kesemua tabel tersebut memiliki relasi one to many. 


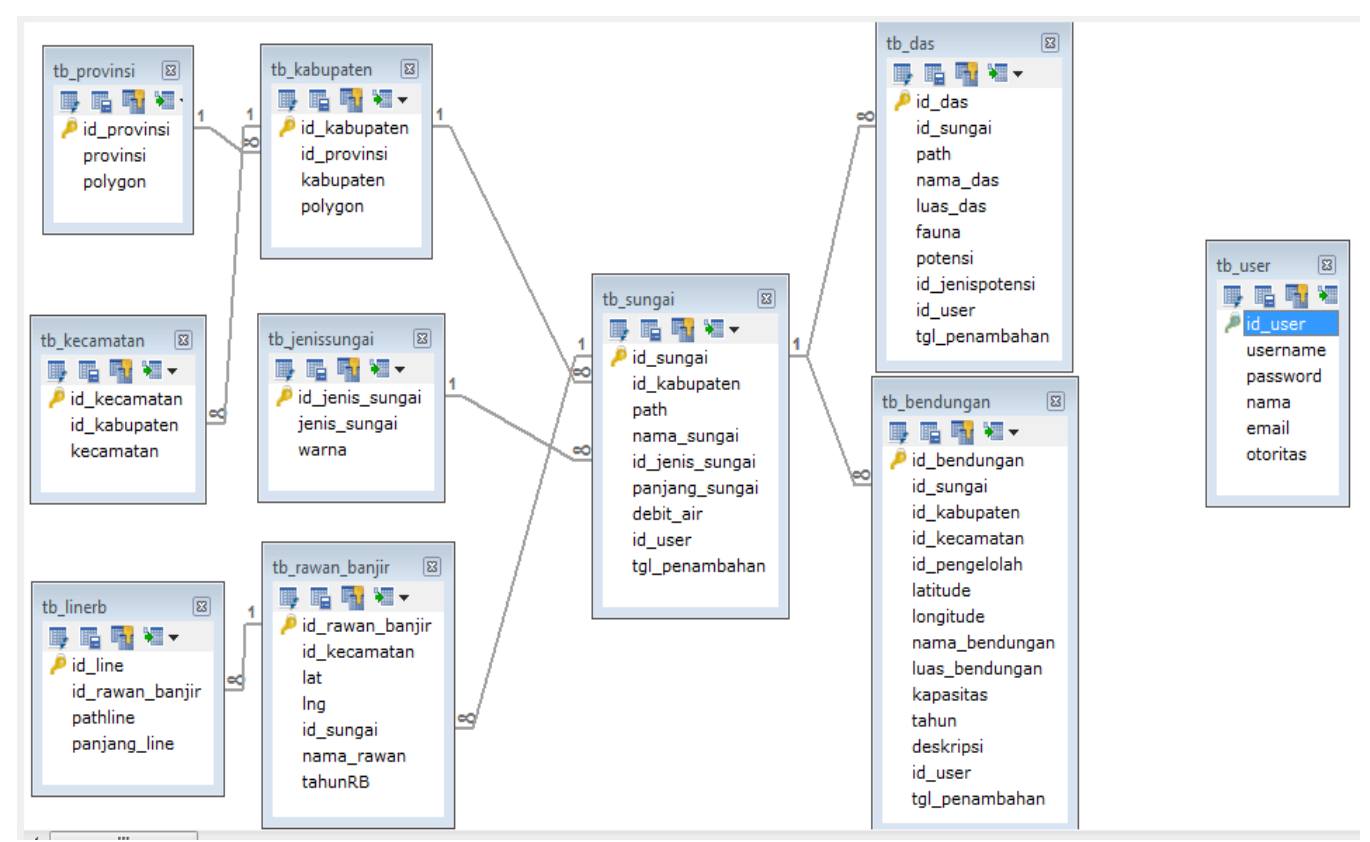

Gambar 3. Relasi Antar Tabel

\section{Kajian Pustaka}

Salah satu studi mengenai DAS juga pernah dilakukan oleh Tesfaye Gebre, Tigist Kibru, Samuale Tesfaye dan Gebeyehu Taye yang mengidentifikasi pentingnya atribut DAS untuk pengelolaan sumber daya air menggunakan ArcGIS software, ASTER DEM dan citra satelit untuk mikro-DAS Chelekot, Tigray, Ethiopia. Penelitian ini juga mengevaluasi parameter hidrologi yang berbeda yang signifikan untuk pengelolaan sumber daya air dalam mikro-DAS dan menemukan solusi alternatif untuk panen air di daerah penelitian melalui pengenalan struktur konservasi tanah dan air yang sesuai berdasarkan temuan. Atribut utama dalam DAS yang diteliti termasuk pola drainase, parameter topografi, jenis penggunaan lahan dan jenis tanah dievaluasi dan diinterpretasikan untuk studi mikro-DAS. Software ArcGIS digunakan untuk perhitungan, penggambaran batas dan morfometrik analisis mikro-DAS menggunakan peta topografi dan data ASTER DEM [3].

\subsection{Daerah Aliran Sungai}

Daerah Aliran Sungai (DAS) didefinisikan sebagai suatu wilayah yang dibatasi oleh pembatas topografi seperti punggung bukit yang menerima, mengumpulkan air hujan, sedimen dan unsur hara lain serta mengalirkannya melalui atau menuju anak-anak sungai dan keluar pada satu titik (outlet). Pengelolaan DAS merupakan suatu kegiatan di dalam melestarikan sumber daya alam dan lingkungan. Mahasiswa UKRIM Yogyakarta Edy Harseno dan Vickey Igor R Tampubolon melakukan penelitian dalam memetakan batas administrasi, tahan, geologi, penggunaan lahan, lereng DIY dan DAS di Jawa Tengah menggunakan Arcview GIS [4].

Penelitian Mahasiswa Jurusan Teknik Sipil tersebut tidak hanya mendata namun juga merepresentasikan data spasial maupun data atribut yang terdapat di Daerah Istimewa Yogyakarta yakni data batas administrasi, data tanah, data geologi, data penggunaan lahan (landuse), data kemiringan lereng dan data DAS di Jawa Tengah. Peneliian ini masih memiliki kekurangan pendataan dan pemetaannya yang kurang sesuai harapan dikarenakan proses penampilan peta pada sistem masih memerlukan proses yang lama dan database dalam sistem tidak bersifat global [4]. 


\subsection{Sistem Informasi Geografis}

Sistem Informasi Geografis adalah sistem informasi khusus yang mengelola data yang memiliki informasi spasial (dimensi keruangan). Sistem informasi geografis adalah bentuk sistem informasi yang menyajikan informasi dalam bentuk grafis dengan menggunakan peta sebagai interface atau antar muka. SIG tersusun atas konsep beberapa lapisan (layer) dan relasi [5].

Fungsi sistem informasi geografis adalah meningkatkan kemampuan menganalisis informasi spasial secara terpadu untuk perencanaan dan pengambilan keputusan. Sistem informasi geografis dapat memberikan informasi kepada pengambil keputusan untuk analisis dan penerapan database keruangan [5].

\subsection{Data Spasial}

Data spasial adalah sebuah data yang berorientasi geografis, memiliki sistem koordinat tertentu sebagai dasar referensinya dan mempunyai dua bagian penting yang membuatnya berbeda dari data lain, yaitu informasi lokasi (spasial) dan informasi deskriptif (attribute) yang dapat dijelaskan sebagai berikut ini :

a. Informasi lokasi (spasial), berkaitan dengan suatu koordinat baik koordinat geografi (latitude dan longitude) dan sebuah koordinat, termasuk diantaranya informasi datum dan proyeksi.

b. Informasi deskriptif (atribut) atau informasi non spasial, berkaitan dengan suatu lokasi yang memiliki beberapa keterangan yang berkaitan dengannya, contohnya : jenis vegetasi, populasi, luasan, kode pos dan lain-lain [6]

\section{Pembahasan}

Hasil dan pembahasan berisi screen shoot sistem yang telah dibangun dan menganalisa hasil yang didapat setelah melakukan pengujian terhadap sistem informasi geografis yang dikembangkan.

\subsection{Interface Sistem Informasi}

Sistem informasi ini memiliki dua user interface, satu untuk panel admin dan satu untuk user. Halaman utama atau index ini merupakan halaman yang pertama kali akan muncul ketika pengguna memasukkan alamat website tentang website Pemetaan Daerah Aliran Sungai. Halaman utama ini terdiri dari beberapa Menu utama yaitu Menu Info DAS, Menu Info Sungai dan Menu Bendungan.

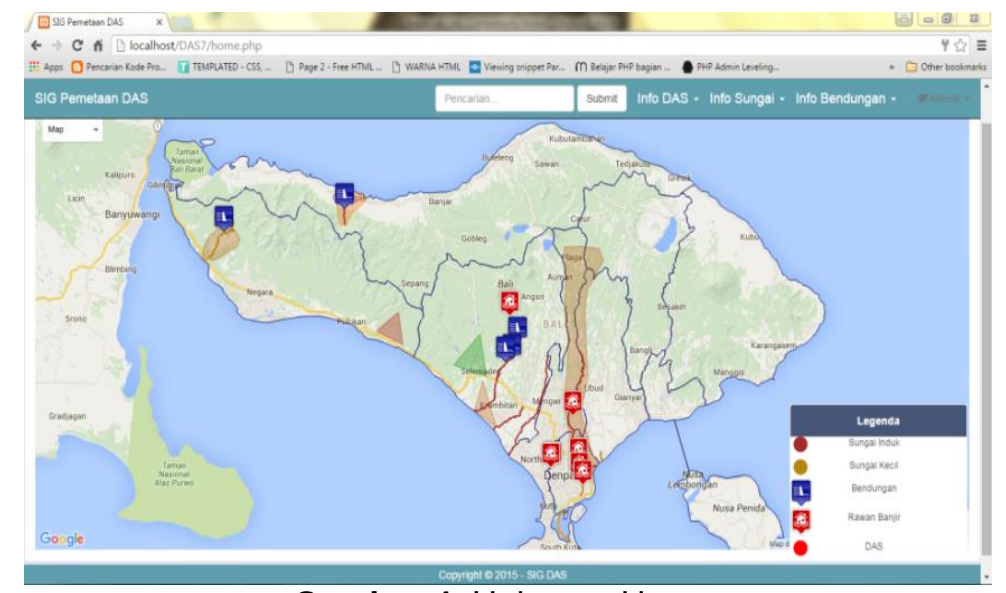

Gambar 4. Halaman Utama

Admin perlu memasukkan nama dan password yang telah tersimpan di database untuk dapat masuk ke panel admin. Panel admin ini memiliki beberapa Menu seperti Menu Maps yang berisi peta untuk melakukan penambahan data spasial bendungan, jaringan sungai, titk rawan banjir, perpanjangan genangan banjir dan batas DAS, Menu Data Tabular yang merupakan Menu untuk memanipulasi data non spasial dan Menu Report untuk pelapolaran. 


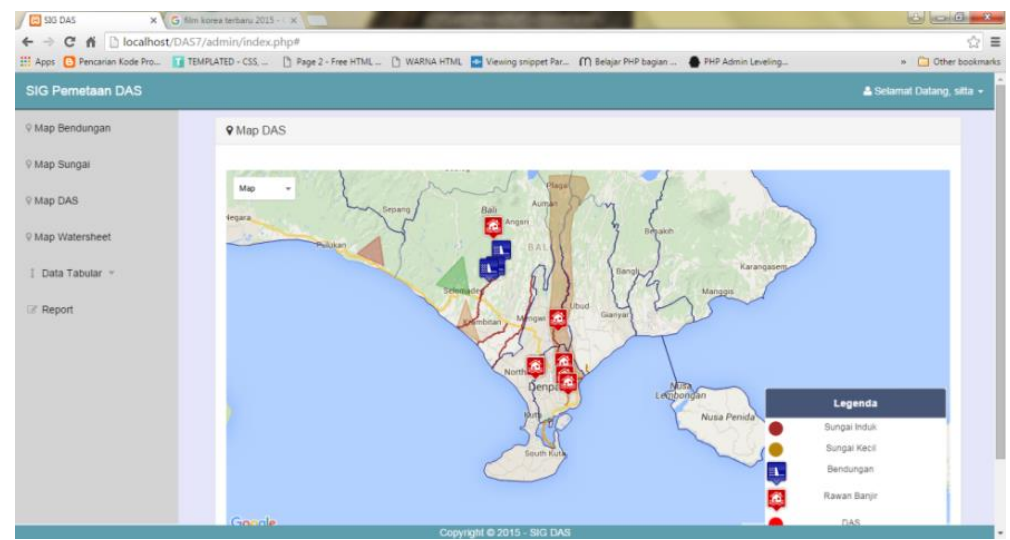

Gambar 5. Panel Admin

Panel admin ini akan langsung terhubung ke halaman utama user, perubahan data yang dilakukan pada panel admin akan langsung tampak pada halaman utama user.

\subsection{Tampilan Tambah Data Spasial Bendungan}

Sistem Informasi Geografis ini mempresentasikan bendungan menjadi sebuah titik atau marker. Bendungan akan terletak diantara sungai utama yang mengalir dalam sebuah Daerah Aliran Sungai. Bendungan akan terletak di titik pada aliran sungai utama yang dibendung.

Cek Box Edit bendungan berfungsi untuk mengaktifkan fungsi Tambah Marker di peta. Admin dapat menambahkan bendungan melalui form yang tersedia dan dapat melakukan edit serta delete marker bendungan melalui infowindow pada peta.
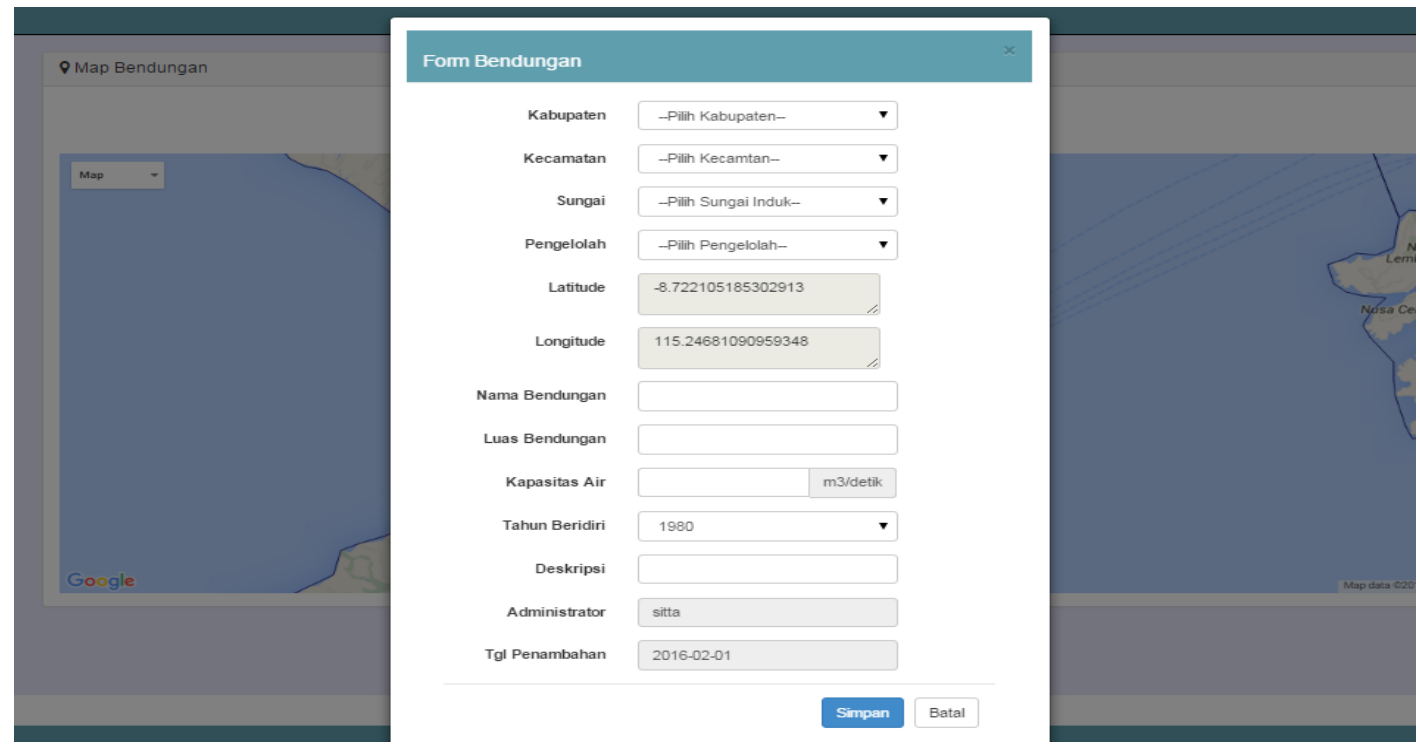

Gambar 6. Menambahkan Data Spasial Bendungan

\subsection{Tampilan Data Non-Spasial Bendungan}

Input data bendungan secara manual dengan menginputkan latitude dan longitude lokasi bendungan, kabupaten dan kecamatan bendungan, nama bendungan, luas bendungan, tahun berdiri kapasitas air, pengelolah bendungan dan deskripsi dari bendungan. Hasil input tersebut akan langsung merujuk pada peta dengan koordinat yang telah di-input-kan dan akan langsung tersimpan pada data bendungan. 


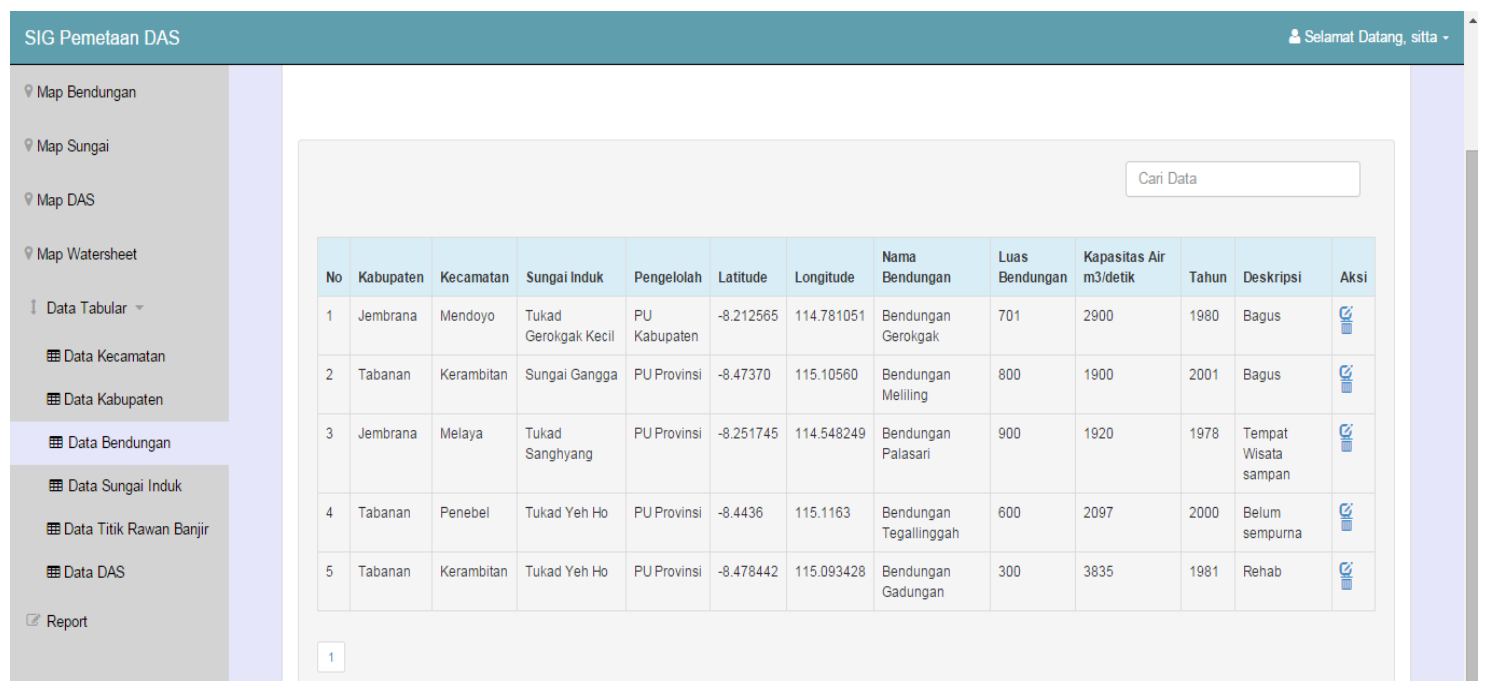

Gambar 7. Data Non-Spasial Bendungan

Admin dapat melakukan edit dan delete terhadap data yang telah dimasukkan baik langsung melalui info window maupun melalui data tabular bendungan.

\subsection{Tampilan Tambah Data Spasial Sungai}

Pembuatan polyline ini ditujukan untuk membuat jaringan sungai induk atau sungai besar dan sungai kecil yang dari atau mengalir menuju sungai induk.

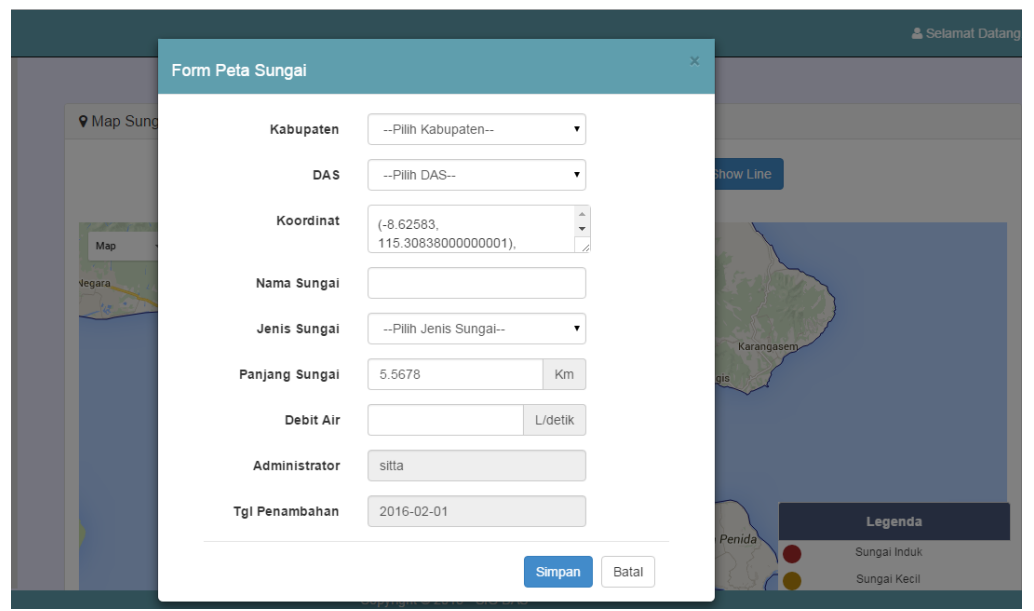

Gambar 8. Tambah Data Spasial Sungai

Banyak titik koordinat yang diklik di peta akan di encode dan disimpan dalam database oleh program. Admin hanya perlu memasukan data yang diperlukan seperti nama sungai, jenis sungai dan rata-rata debit air sungai.

\subsection{Tampilan Data Non Spasial Sungai}

Input data sungai secara manual dengan menginputkan kumpulan latitude dan longitude lokasi aliran sungai, kabupaten dengan panjang aliran terpanjang, nama sungai, jenis sungai, panjang sungai dan debit air. Hasil input tersebut akan langsung merujuk pada peta dengan koordinat yang telah di-input-kan dan akan langsung tersimpan pada data sungai. 


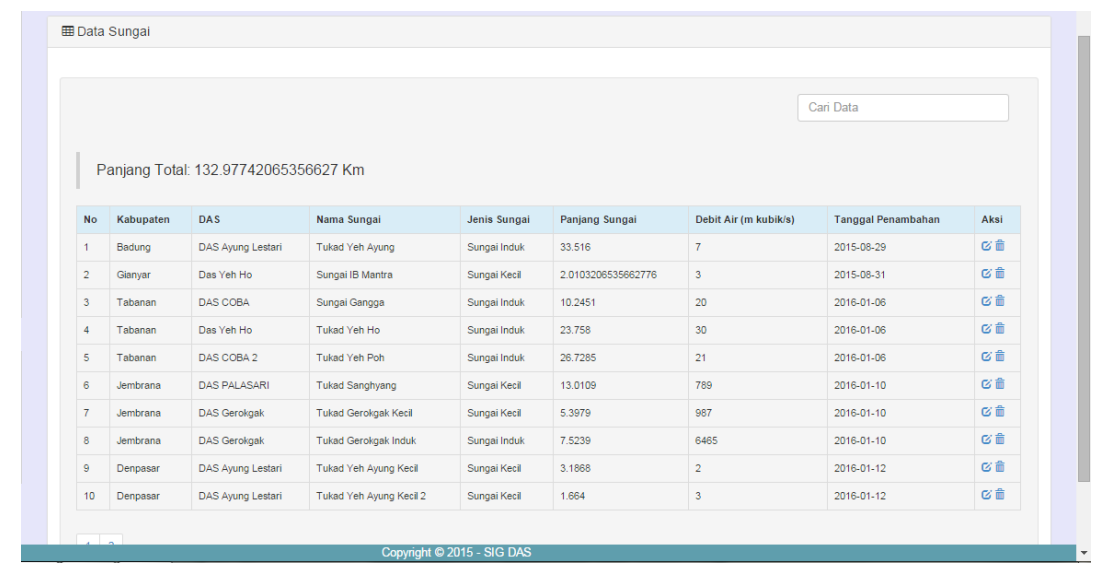

Gambar 9. Data Non Spasial Sungai

Data tabular sungai ini menyimpan seluruh data sungai yang telah di-input oleh admin baik melalui peta sungai maupun melalui data tabular. Admin dapat melakukan searching berdasakan nama sungai, jenis sungai dan kabupaten.

\subsection{Tampilan Tambah Data Spasial DAS}

Pembuatan sebuah polygon berawal dari sebuah polyline yang dihubungkan. Snapping membantu untuk menyatukan antara marker satu dengan yang lain agar tidak terdapat jarak antar keduanya. Snapping berguna untuk pembuatan sebuah aliran sungai yang berupa polyline dan pembuatan batas Daerah Aliran Sungai yang berupa polygon.

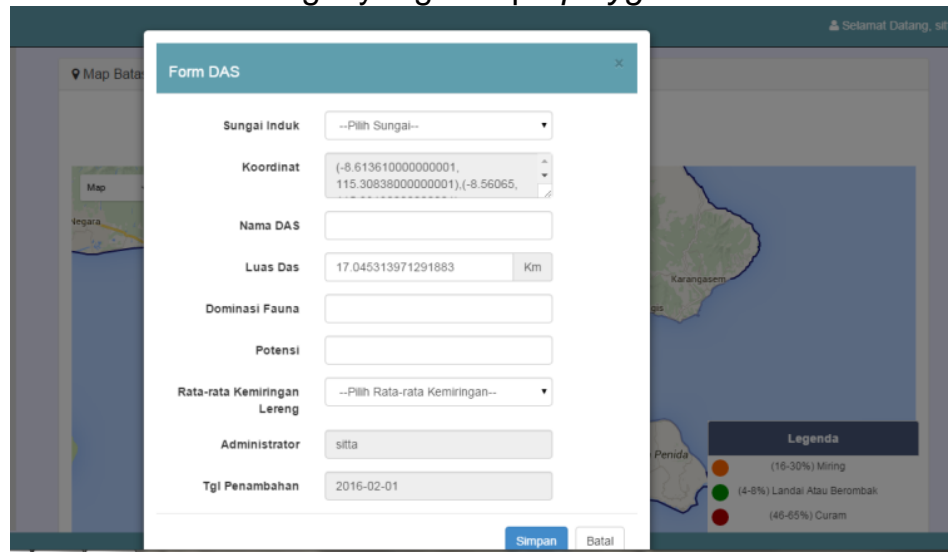

Gambar 10. Penambahan Data Spasial DAS

Polygon Daerah Aliran Sungai merupakan sebuah batas teritorial utara, selatan, barat dan timur dari sebuah sungai utama. Satu sungai utama dalam teritorial DAS biasanya memiliki beberapa subsistem atau sungai kecil yang mengalir menuju sungai utama.

\subsection{Tampilan Tambah Data Non Spasial DAS}

Input data DAS secara manual dengan menginputkan kumpulan latitude dan longitude lokasi DAS, nama DAS, sungai induk yang mengalir, rata-rata kemiringan lereng serta jenis fauna dominan yang terdapat dalam DAS. Hasil input tersebut akan langsung merujuk pada peta dengan koordinat yang telah di-input-kan dan akan langsung tersimpan pada data DAS. 


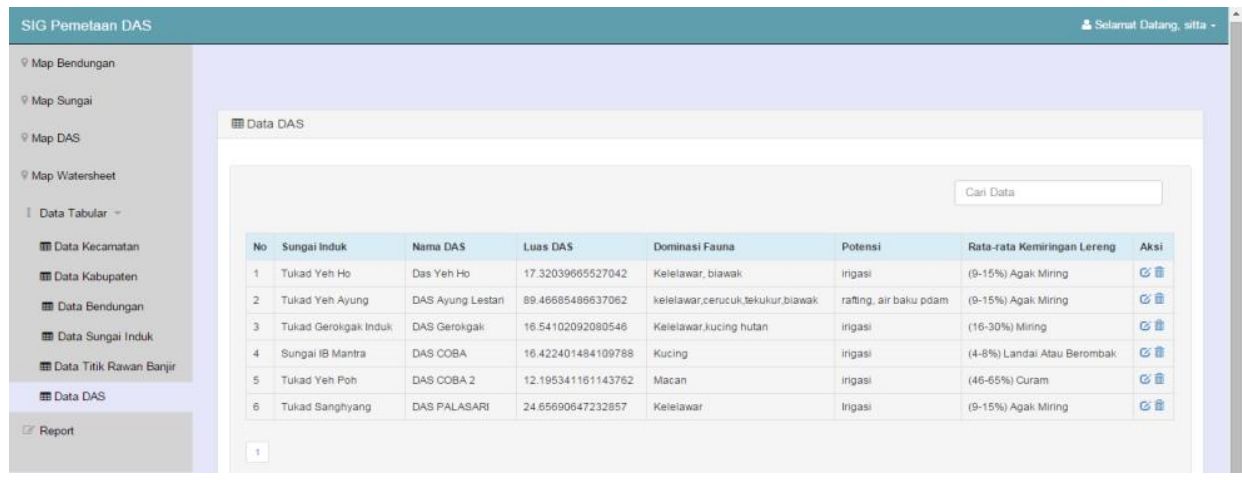

Gambar 11. Data Non Spasial DAS

Admin dapat melakukan edit dan delete batas DAS melalui data tabular. Admin juga dapat melakukan searching berdasarkan nama DAS dan nama sungai induk yang mengalir.

\subsection{Menu Report}

Menu Report atau pelaporan berisi semua data yang telah di-input oleh admin kedalam sistem. Menu Report sendiri terbagi menjadi empat bagian, yaitu report bendungan yang dapat mengelompokkan jumlah bendungan berdasarkan kabupaten dan tahun berdirinya bendungan. Admin juga dapat memilih untuk mencetak seluruh data, mencetak data berdasarkan kata kunci pencarian tertentu atau mengconvert data ke excel.

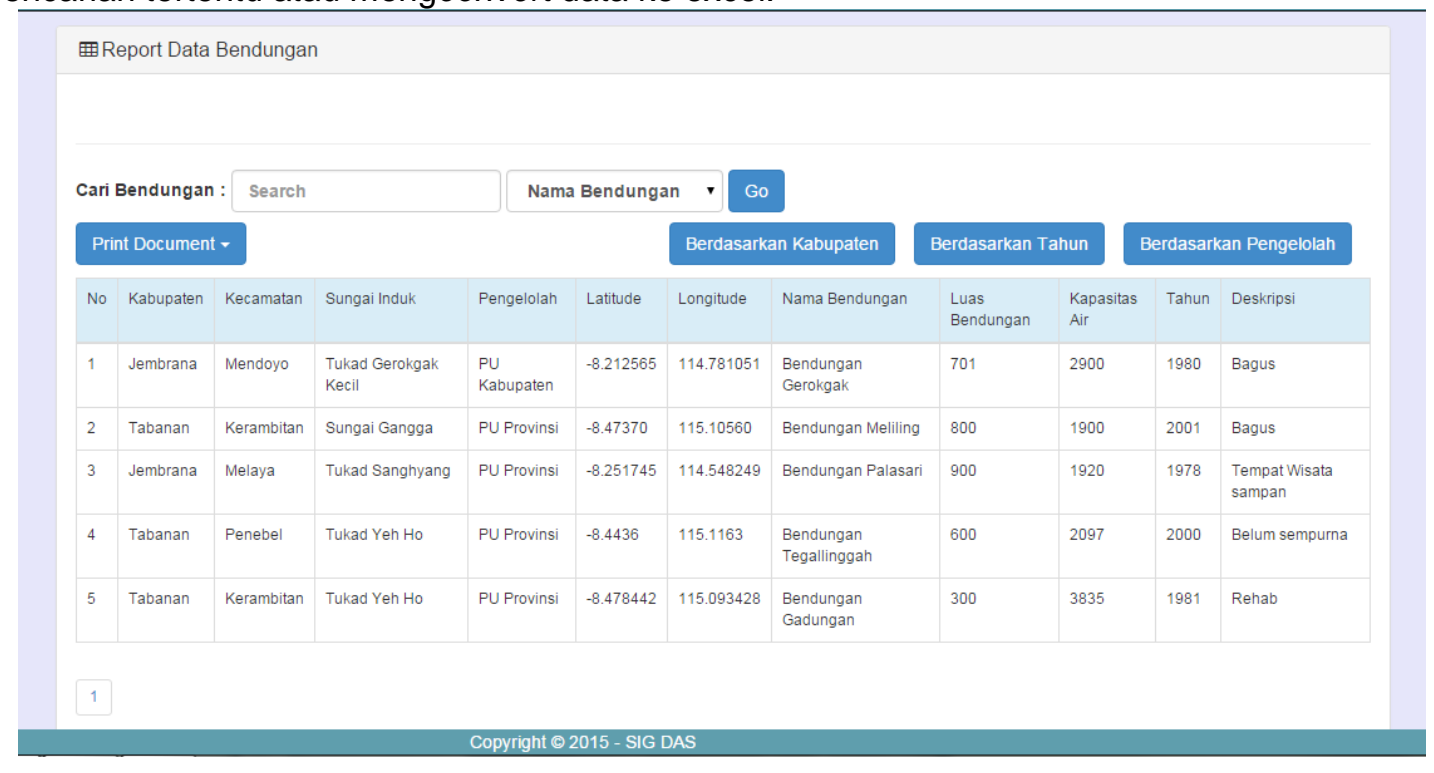

Gambar 12. Report Bendungan

Report sungai tidak jauh berbeda dengan report bendungan. Report sungai mengelompokan sungai berdasarkan jumlah sungai yan melintasi sebuah wilayah atau kabupaten. Admin juga dapat memilih untuk mencetak seluruh data sungai, mencetak data berdasarkan kata kunci pencarian tertentu atau mengconvert data ke excel. 
円Report Data Sungai

Cari Sungai : Search $\quad$ Nama Sungai $~ G$

\section{Print Document -} Nama Sungai

Badung

\section{DAS}

Gianyar

DAS Ayung Lestar

Tukad Yeh Ayung

Sungai B Mantra

Das Yeh Ho

Sungai Gangga

Tabanan DAS COBA

Tukad Yeh Ho

Tabanan

Das Yeh Ho

Turares

Tabanan DAS COBA 2

Jembrana

DAS PALASARI

Tukad Sanghyang

Jembrana

DAS Gerokgak

Tukad Gerokgak Ke

Tukad Gerokgak Induk

DAS Gerokgak

Denpasar

DAS Ayung Lestar

Tukad Yeh Ayung Keci

DAS Ayung Lestari

Tukad Yeh Ayung Kecil 2

\section{Jenis Sungai}

Sungai Induk

Sungai Kecil

Sungai Induk

Sungai Induk

Sungai Induk

Sungai Kecil

Sungai Kecil

Sungai Induk

Sungai Kec

Sungai Kecil

\section{Panjang Sungai}

33.516

2.0103206535662776

10.2451

23.758

26.7285

13.0109

5.3979

7.5239

3.1868

1.664

\begin{tabular}{|l|l|} 
& \\
& Lihat Jumlah Sungai \\
\hline Tanggal Penambahan & Jumlah Titik Rawan Banjir \\
\hline $2015-08-29$ & 2 \\
\hline $2015-08-31$ & 0 \\
\hline $2016-01-06$ & 0 \\
\hline $2016-01-06$ & 0 \\
\hline $2016-01-06$ & 0 \\
\hline $2016-01-10$ & 0 \\
\hline $2016-01-10$ & 0 \\
\hline $2016-01-10$ & 0 \\
\hline $2016-01-12$ & 0 \\
\hline $2016-01-12$ & 6 \\
\hline
\end{tabular}

Gambar 13. Report Sungai

Report rawan banjir adalah menu pelaporan yang berisi seluruh data rawan banjir dan mengelompokkan jumlah titik rawan banjir berdasarkan kabupaten dan tahun munculnya titik rawan banjir tersebut.

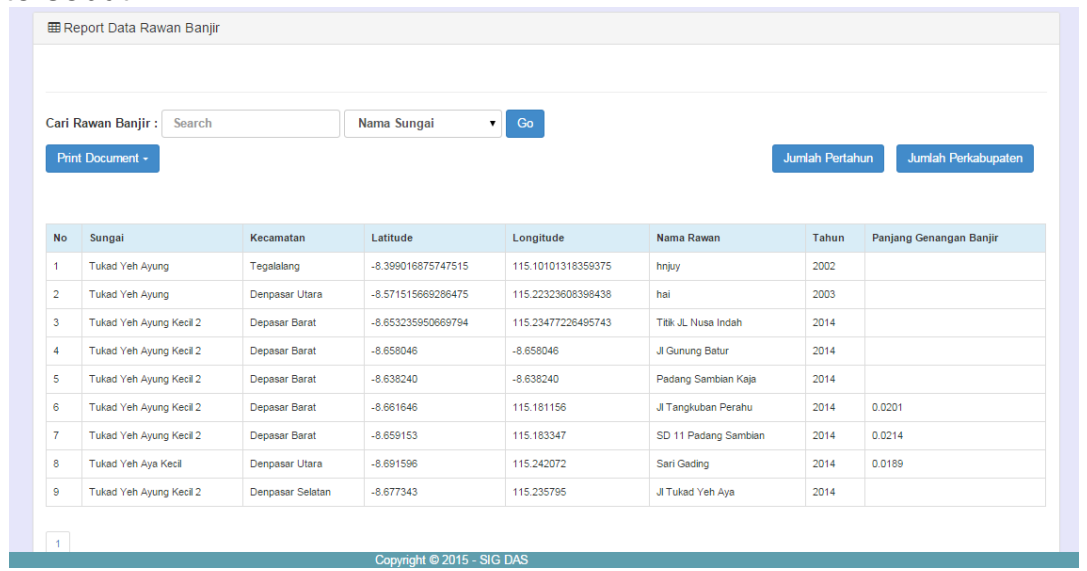

Gambar 14. Report Titik Rawan Banjir

Admin dapat melihat grafik pertumbuhan jumlah titik rawan banjir melalui menu jumlah pertahun. Admin hanya perlu memilih tahun untuk menampilkan jumlah rawan banjir.

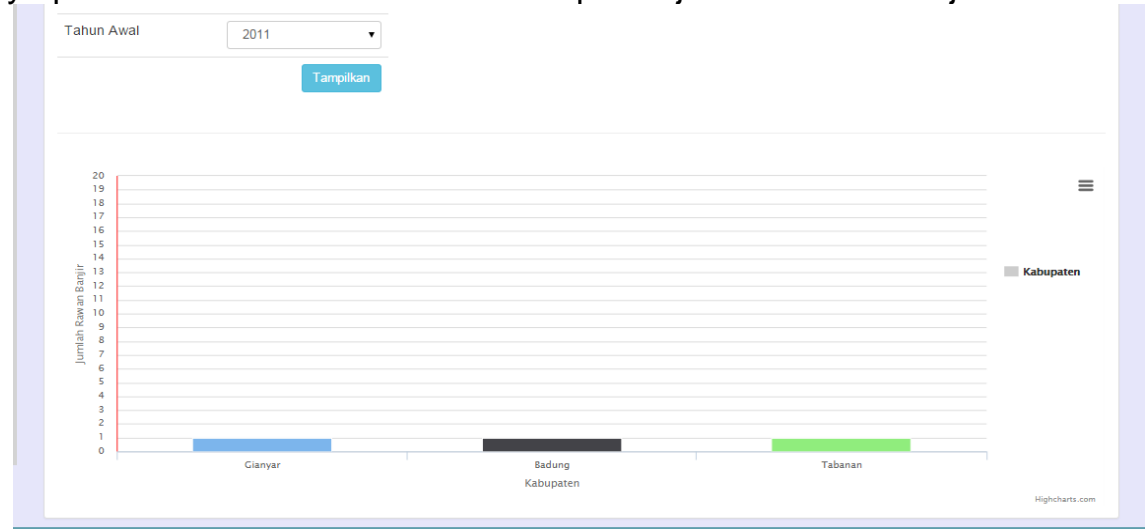

Gambar 15. Chart Titik Rawan Banjir 
Sistem akan menampilkan jumlah titik rawan banjir pada kabupaten tertentu. Chart ini akan menunjukkan kabupaten mana yang memiliki titik rawan banjir teranyak dalam satu tahun. Report DAS dalam sistem informasi ini memiliki perbedaan dari report lainnya. Report DAS dalam sistem ini menggabungkan semua data mulai bendungan yang terdapat dalam DAS, sungai yang mengalir dalam DAS dan jumlah titik rawan banjir dalam DAS.

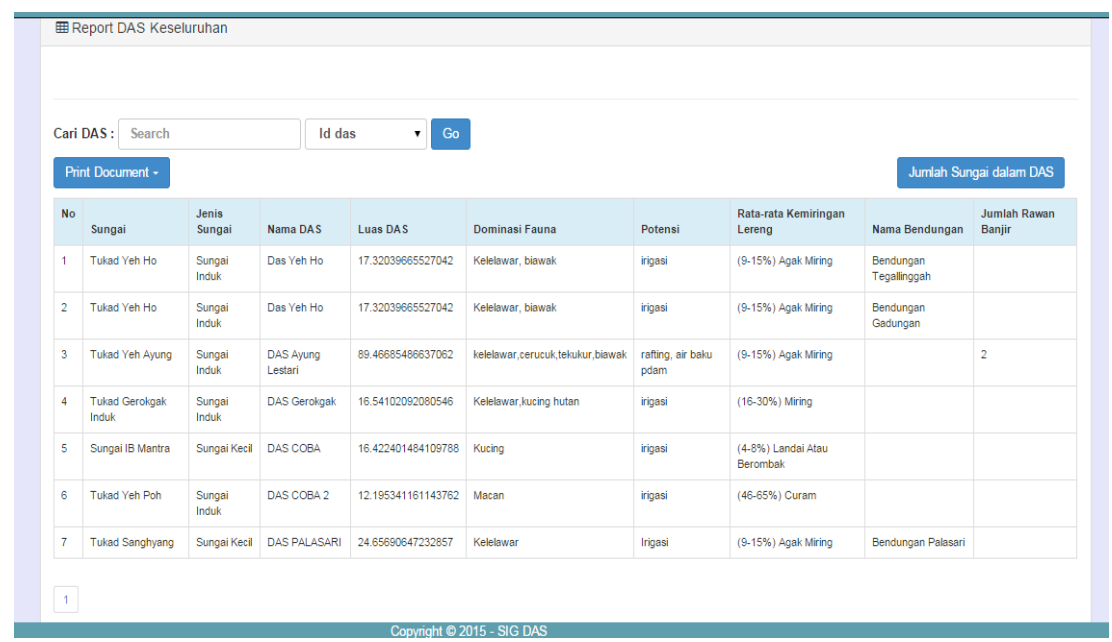

Gambar 16. Report DAS Total

Report ini menggabungkan hampir semua data dalam sistem. Report ini menampilkan batas DAS, sungai induk yang mengalir dalam DAS, bendungan yang terdapat dalam DAS dan jumlah titik rawan banjir yang dimiliki.

\section{Kesimpulan}

Sistem Informasi Geografis Pemetaan Daerah Aliran Sungai Berbasis Web dapat diakses oleh user untuk mendapatkan informasi mengenai lokasi bendungan beserta deskripsinya, jaringan sungai di tiap kabupaten dan panjang sungai tersebut, titik rawan banjir di sepanjang sungai beserta perpanjangan genangan banjir tersebut serta informasi mengenai batas DAS. Sistem ini juga bisa dimanfaatkan oleh pihak terkait guna perencanaan, pengambilan keputusan dan pelestarian DAS untuk meminimalisir terjadinya bencana yang disebabkan oleh luapan air sungai.

\section{Daftar Pustaka}

[1] H. Sifurridza, "Penerapan Penginderaan Jarak Jauh Menggunakan Sistem Informasi Geografis untuk Menentukan Parameter Fisik Daerah Aliran Sungai (Lokasi Studi : Sub DAS Sumber Brantas)," 2013.

[2] H. M. Jogiyanto, Analisis Dan Disain Sistem Informasi : Pendekatan Terstruktur Teori Dan Aplikasi Bisnis. Yogyakarta: Andi Offset, 2005.

[3] T. Gebre, T. Kibru, S. Tesfaye, and G. Taye, "Analysis of Watershed Attributes for Water Resources Management Using GIS: The Case of Chelekot Micro-Watershed, Tigray, Ethiopia," Jurnal Geographic Information System, vol. 7, no. 2, pp. 177-190, 2015.

[4] E. Harseno and V. I. R. Tampubolon, "Aplikasi Sistem Informasi Geografis Dalam Pemetaan Batas Administrasi, Tanah, Geologi, Penggunaan Lahan, Lereng, Daerah Istimewa Yogyakarta Dan Daerah Aliran Sungai Di Jawa Tengah Menggunakan Software Arcview Gis," Majalah IImiah UKRIM, vol. 1, pp. 63-80, 2007.

[5] E. Prahasta, Konsep-konsep Dasar SIG. Bandung: Informatika, 2002.

[6] E. Prahasta, Sistem Informasi Geografis Konsep-Konsep Dasar (Perspektif Geodesi \& Geomatika). Bandung: Informatika, 2014. 